\title{
Notes on the Moult of the Eastern Great Reed Warbler Acrocephalus arundinaceus orientalis in the Breeding Grounds*
}

\author{
Yasuo Ezaki**
}

\begin{abstract}
During the course of an ecological study of the Eastern Great Reed Warbler Acrocephalus arundinaceus orientalis at Lake Biwa, some information on its moulting was obtained. From 1976 to 1978, 24 birds were trapped after July and 9 of them, including both young and adults, were either during or after moult. Their stage of moult agrees closely with the progress of moulting in young and adults at Fukushimagata, estimated from the moulting records of the BMRC banding team. Some birds that bred in the study site were confirmed to start moult there and it is expected that they complete it not far from their breeding sites. Characters for ageing were also referred to.
\end{abstract}

Great Reed Warbler Acrocephalus arundinaceus has a wide breeding range in the Palaearctic region. Its far eastern race $A$. a. orientalis breeds in Japan and winters in SouthEast Asia (Dement'ev \& Gladkov 1954). Although post-nuptial moult of this race was known to take place in the breeding range (Williamson 1968), it was not until the systematic mist-netting by the BMRC banding team at Fukushimagata, Niigata Prefecture, northern Japan, that any quantitative data about its moulting were obtained. They confirmed that not only adults but also young birds undergo a complete moult before migration and also showed that the moulting season of adults ends earlier than that of young (BMRC 1978). During my ecololgical study of this race at Lake Biwa, some information on its moulting was obtained. Moulting in this species is supposed to have a great influence on its breeding ecology at the end of the breeding season (Ezaki in prep.).

The research was conducted in a reed marsh at the coast of Lake Biwa near the Kono-hama Town, Moriyama City, Shiga Prefecture. The study site has been described in detail by Ezaki (1981). Active broods existed from early May to late July or early August. From 1976 to 1978, mist netting was conducted for the purpose of banding birds, with usual observations being made from the tower built at the centre of the marsh. The plumage of trapped birds was examined. Ageing of birds before moulting was easy because young have distinctive juvenile plumages, but once moulting starts, this character cannot be used. Young birds of this species are known to have dark eyes and a pair of dark spots on the tongue (Kakizawa 1974) and therefore these characters were also checked. The stage of moult was recorded using the B. T. O. system after Abe et al. (1974), in which each growing feather is scored from 1 to 4 according to its stage of growth; a full grown feather being scored 5 . This gives a total of 45 points for a complete primary moult of one wing, as the tenth primaries are rudimentary. Birds before moult have 0 points.

* Contribution from the Laboratory of Animal Ecology, Department of Zoology, Kyoto University, No. 463.

** Department of Zoology, Faculty of Science, Kyoto University, Sakyo-ku, Kyoto 606. 


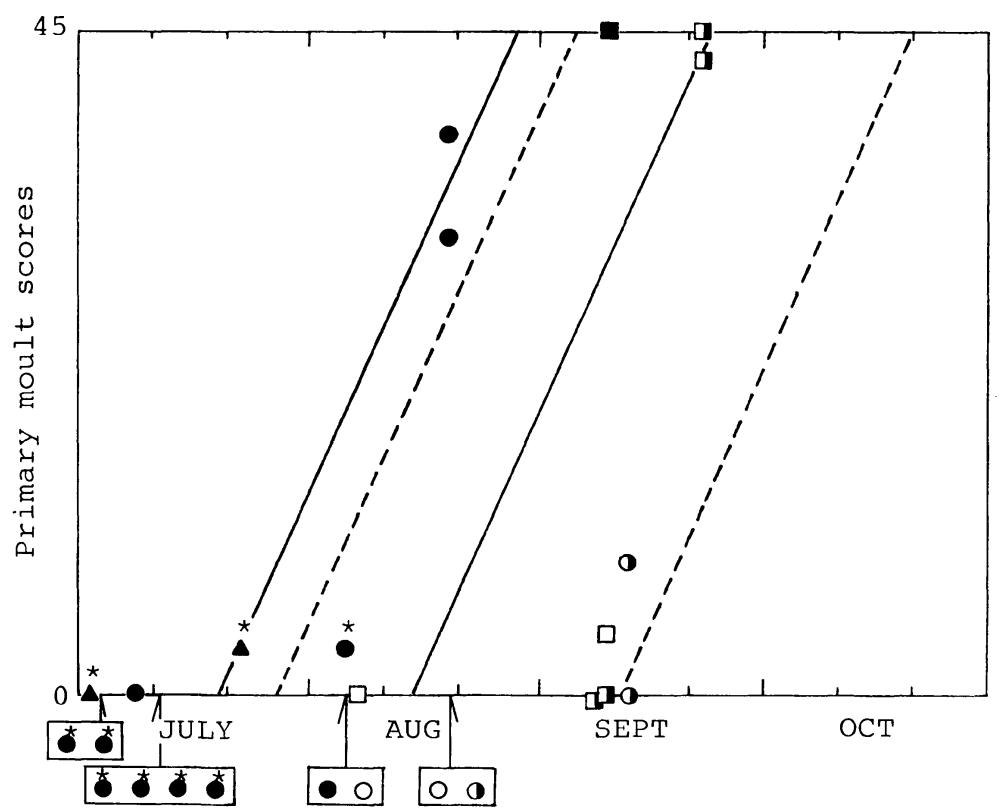

Fig. 1. Moulting season at Fukushimagata and moulting records of Lake Biwa. "Moulting belts" of adults (between two solid lines) and young (between two dashed lines) at Fukushimagata were drawn from BMRC (1978), assuming that an individual bird takes 40 days for a complete primary moult. Birds of Lake Biwa are indicated by triangles (1976), circles (1977) and squares (1978). Solid, open and half-solid symbols are adults, young with clear tongue spots and young with paler tongue spots, respectively. Asterisks are attached to the breeders in the study site.

No birds were observed or trapped in moult before June. From July to September, a total of 25 birds were trapped, including an adult trapped twice before moult in the same season. Fifteen birds were before moult and nine were during or after moult. Ageing of the former was done by their plumages and eight adults had light eyes and no tongue spots, contrasting with seven young having dark eyes and tongue spots. Combination of the two characters was also complete in the latter, and four young were accurately distinguished from five adults.

Trapping and moulting records at Fukushimagata are available only after late August (BMRC 1978) and do not cover the whole moulting season. However, as birds with complete new feathers appeared there after September, the moulting season can be estimated, given the period needed for a bird's primary moult. That of young is reported as 30 to 40 days (BMRC 1978). In the western race, Hillman \& Young (1977) reported that hand-raised young birds took 41 days in average for the primary moult. Assuming it is 40 days for both young and adults, their moulting seasons at Fukushimagata were expressed as two "moulting belts" (Fig. 1). Points of each age class at Lake Biwa are contained almost completely in the belt of adults and young at Fulushimagata.

It is impotant in my study that birds which bred in the study site were confirmed to 


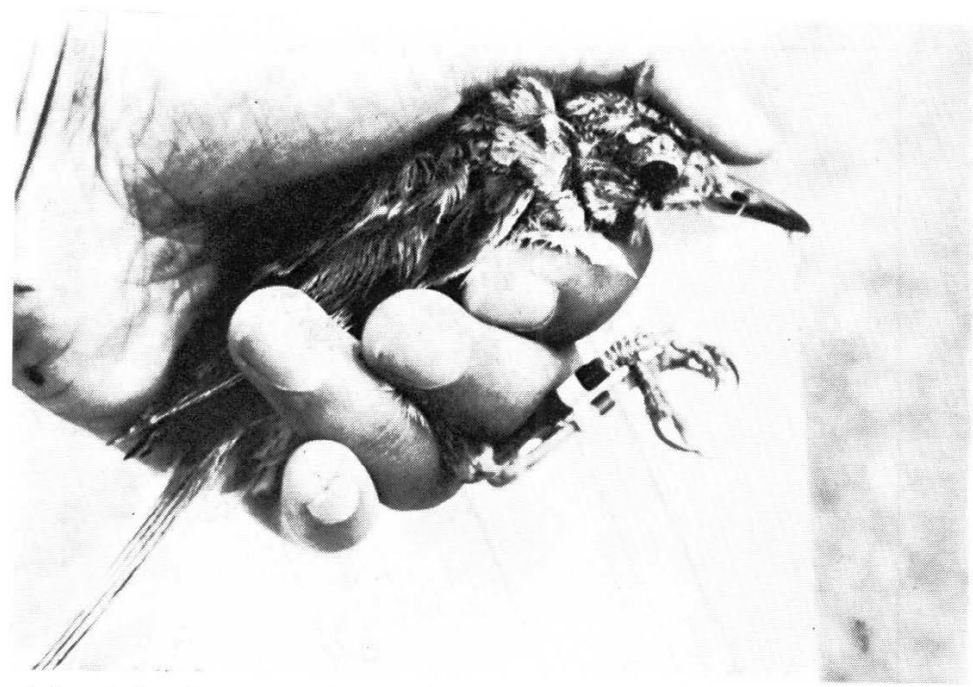

Fig. 2. A banded male captured in moult on 22 July 1976. He had held a territory in the study site until a week before. His stage of moult is given in the text.

be in moult there by their leg bands (see Fig. 1). One was a male trapped on 22 July 1976 (the earliest moulting record) which had held a territory in the study site until 15 July. Another was a female trapped on 5 August 1977 which was rearing a brood in the study site until 30 July of that year. The two birds were almost in the same stage of moult and had lost the inner three primaries and all of the greater coverts. Their tail feathers were worn out and the head of the male was almost naked (Fig. 2). When released, they could not make a level flight, giving support to the poor flight ability noted by Kakizawa (1974).

By observations from the tower two other banded adults were confirmed to be in moult. On 27 July 1977, a banded bird, moving slowly and silently near the base of the reed stems, was witnessed as it passed at the foot of the tower. From the leg band pattern it was identified as a male that had held a territory near the tower 15 days before. His worn plumage indicated that he was in the midst of moulting, but he was only observed for a short time. On the same day, another banded adult in moult was also witnessed from the tower. Although this individual did not breed in the study site, it had been trapped on 27 June of that year and was inferred to have spent that breeding season near the area. Thus at least some birds start their moulting days near their breeding sites. Their poor flight ability would prevent them from dispersing widely until the completion of the moult.

Lastly, tongue spots for ageing must be referred to. They had a tendency to get paler with season of the year (see Fig. 1) and those of the latest trapped (22 September) were nearly vanished and therefore this character may not be so useful late in the moulting season. 


\section{Acknowledgements}

Thanks are due to Mr Nozomu Miyazawa, Mr Hisashi Sugawa and members of the Bird Migration Research Center of the Yamashina Institute for Ornithology for their help and advice in bird banding. I am also grateful to Dr. Hiroya Kawanabe, Dr. Andrew Rossiter and other members of the Laboratory of Animal Ecology, Kyoto University for their critical comments on the manuscript.

\section{References}

Abe, N., Higuchi, H., Saito, T., Matsuyama, S. \& Sasagawa, A. 1974. Moult of some birds captured at Subashiri banding area, Mt. Fuji. Misc. Rep. Yamashina Inst. Ornith. 7: 404-426. (in Japanese).

BMRC (Bird Migration Research Center, Yamashina Institute for Olnithology) 1978. Report of the Bird Migration Research Center (February 1, 1978-January 31, 1979). (in Japanese).

Dement'ev, G. P. \& Gladkov, N. A. (eds.) 1954. Birds of the Soviet Union. Vol. VI. Moscow.

Ezaki, Y. 1981. Female behaviour and pair relation of the polygynous great reed warbler Acrocephalus arundinaceus (Aves: Sylviinae). Physiol. Ecol. Japan 18: 77-91.

Hillman, A. \& Young, C. 1977. Observations on the moult of the great reed warbler Acrocephalus arundinaceus. Ibis 119: 204-207.

Kakizawa, R. 1974. Migratory season of eastern great reed-warbler Acrocephalus arundinaceus in Niigata Prefecture. Bull. Nagaoka Municipal Science Museum 9:49-54. (in Japanese).

Williamson, K. 1968. Identification for ringers. 1. The genera Cettia, Locustella, Acrocephalus and Hippolais. Revised ed. B.T.O.

\section{オオヨシキリ Acrocephalus arundinaceus orientalis の換羽について}

1) 琵琶湖でのオオョシキリの生態調査中にこの種の換羽について若干の知見を得た。

2) 1976-1978 年の 7 月以降什計 24 羽を捕獲した。この5ち成鳥 5 羽, 幼鳥 4 羽が換羽中もしくは, 換羽後の個体であった。初列風切羽の換羽状況を点数法をもちいて記録した。

3) 山階鳥類研究所の標識チームによる福島潟での 換羽記録から換羽の季節的な進行を成鳥，幼鳥それ ぞれについて推定したところ，琵琶湖の記録はこれにほぼ適合した。

4）調査地内で繁殖した個体が同地で換羽を開始していることが捕獲と観察によって確認された。換羽 中には飛翔力が著しく低下することがわかっているので，これらの成鳥は繁殖場所をあまり離れることな く換羽を完了するものと予想できる。

5）幼鳥の形態的特徵と，換羽中の成幼の識別におけるその有効性について子触れた。

江崎保男：京都大学理学部動物学教室。京都市左京区北白川追分町。 